\title{
The SCOPE AND MEANING OF REASONABLENESS REVIEW
}

\author{
PAUL DALY*
}

This article draws attention to the post-Dunsmuir framework regarding the standard of review of administrative action and the Supreme Court of Canada's reluctance to engage in grand theorizing about the general principles of judicial review. The article explores the uncertainty surrounding the application of the standard of reasonableness and what factors can or should be taken into consideration during its application. The article identifies four key problems - the scope of the post-Dunsmuir framework, the scope of its correctness category, the difficult relationship between the reasons given for a decision and the substantive reasonableness of the decision in question, and the emergence of difficult distinctions bedevilling the application of the reasonableness standard. Through identifying weaknesses in the current administration of reasonableness review, it is hoped that the courts, sooner rather than later, will adopt a unified approach for using the reasonableness standard of review.
Cet article attire l'attention sur le cadre de travail suite à la cause Dunsmuir en ce qui concerne la norme de contrôle judiciaire et l'hésitation de la Cour suprême du Canada à élaborer de grandes théories sur les principes généraux du contrôle judiciaire. Cet article examine l'incertitude relative à l'application de la norme du raisonnable et les facteurs qui doivent, ou devraient, entrer en compte lors de cette application. Quatre grands problèmes y sont définis, notamment la portée de la décision de la cause Dunsmuir, la portée de la catégorie du bien-fondé, la difficile relation entre les raisons invoquées pour la décision et le caractère raisonnable important de la décision en question, ainsi que l'émergence de distinctions difficiles embrouillant l'application du raisonnable. Il faut espérer qu'en déterminant les faiblesses de l'administration actuelle de la norme du raisonnable dans le contrôle judiciaire, les tribunaux adopteront, dès que possible, une démarche unifiée quant à l'application de la norme du raisonnable pour le contrôle judiciaire.

\section{TABLE OF CONTENTS}

I. INTRODUCTION . . . . . . . . . . . . . . . . . . . . . . . 800

II. THE SCOPE OF THE POST-DUNSMUIR FRAMEWORK $\ldots \ldots \ldots \ldots \ldots 801$

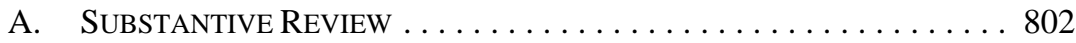

B. Procedural Review $\ldots \ldots \ldots \ldots \ldots \ldots \ldots \ldots \ldots \ldots . \ldots \ldots$

III. THE SCOPE OF THE CORRECTNESS CATEGORIES . . . . . . . . . . . 809

IV. REASONS AND REASONABLENESS REVIEW . . . . . . . . . . . . . . 814

A. DeCiSION-MAKERS SUPPLEMENTING THE RECORD $\ldots \ldots \ldots \ldots 815$

B. JUDICIAL SUPPLEMENTATION OF

ADMINISTRATIVE DECISIONS . . . . . . . . . . . . . . . 817

V. The Rise of Difficult Distinctions $\ldots \ldots \ldots \ldots \ldots \ldots \ldots \ldots . \ldots . \ldots 19$

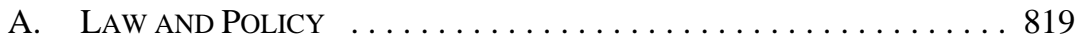

B. IMPLIED AND EXPRESS

COMPONENTS OF DECISIONS $\ldots \ldots \ldots \ldots \ldots \ldots \ldots \ldots \ldots$

C. Clear and Unclear Statutory Provisions $\ldots \ldots \ldots \ldots . \ldots 21$

Associate Dean and Faculty Secretary, Faculty of Law, University of Montreal. A version of this article was presented as the keynote Year in Review address to the Law Society of Upper Canada's 6-Minute Administrative Lawyer event in March 2014. Portions were also presented at the Ontario Bar Association's annual Year in Review event in October 2013. Many thanks to the organizers, participants, and audience members at those events for allowing me the opportunity to hone the points made. Two anonymous reviewers made insightful comments. Extracts have also appeared on my blog, Administrative Law Matters. Thanks are also due to my online interlocutors in the blog's comments section and on Twitter. 
D. APPLiCATION AND INTERPRETATION . . . . . . . . . . . . . . 822

E. Reasoning Process and Substantive Outcomes . . . . . . . 825

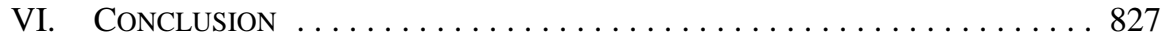

\section{INTRODUCTION}

Questions continue to abound about the standard of review of administrative action in Canada. For something apparently simplified in Dunsmuir v. New Brunswick ${ }^{1}$ and subsequent cases, ${ }^{2}$ it provokes a great many questions. ${ }^{3}$

The key question now, in light of the "triumph" of reasonableness, ${ }^{4}$ is the scope and meaning of reasonableness review. To what does the standard of reasonableness apply and, when it does, what does it mean? Unfortunately, we have had little concrete guidance from the Supreme Court of Canada in recent years. ${ }^{5}$

There are four difficult issues, each of which is shrouded in uncertainty. The first is the scope of the post-Dunsmuir framework: does it apply to regulations issued by a Minister or a cabinet, and are questions of procedural fairness now covered as some appellate judges have suggested? The second is the scope of the categories to which a standard of correctness applies. The third is the ability of decision-makers to bolster their decisions after judicial review proceedings have been commenced. The fourth is the revival and development of troublesome distinctions - between "law" and "policy," "clear" and "unclear" statutory provisions, and "implied" and "express" components of decisions. The latter are designed to implement a unified reasonableness standard that varies according to a "context" ${ }^{\text {" created }}$ by an amorphous group of "all relevant factors."7

A unifying "meta" theme is the Court's reluctance to engage in grand theorizing about the post-Dunsmuir framework. Some of the Court's interventions have had the unfortunate effect of increasing the uncertainty about the scope and meaning of reasonableness review. Without some grand theorizing, it is likely that questions about the standard of review analysis will continue to abound. This article does not offer much in the way of a grand theory. ${ }^{8}$ Rather, it attempts to identify the key problems that require some sustained engagement from the Court and other actors in the legal community. It also offers some modest suggestions on how to improve the current state of the law.

4
Paper].
2008 SCC 9, [2008] 1 SCR 190 [Dunsmuir].

See most notably, Smith v Alliance Pipeline Ltd, 2011 SCC 7, [2011] 1 SCR 160 [Alliance Pipeline], which set out categories of decision to which the standards of correctness and reasonableness apply; and Alberta (Information and Privacy Commissioner) v Alberta Teachers' Association, 2011 SCC 61, [2011] 3 SCR 654 [Alberta Teachers'], which established a presumption of deference when a decision-maker is interpreting its home statute.

See generally, David Mullan, "Unresolved Issues on Standard of Review in Canadian Judicial Review of Administrative Action — the Top Fifteen!” (2013) 42:1 Adv Q 1.

The Honourable John M Evans, “Triumph of Reasonableness: But How Much Does It Really Matter?” (2014) 27:1 Can J Admin L \& Prac 101.

As we shall see, the Court's recent decision in Canadian National Railway Co v Canada (AG), 2014 SCC 40, [2014] 2 SCR 135 [Canadian National] represents a welcome step towards greater clarity. Canada (Minister of Citizenship and Immigration) v Khosa, 2009 SCC 12, [2009] 1 SCR 339 at para Catalyst Paper Corp v North Cowichan (District), 2012 SCC 2, [2012] 1 SCR 5 at para 18 [Catalyst

See Paul Daly, A Theory of Deference in Administrative Law: Basis, Application and Scope (Cambridge, UK: Cambridge University Press, 2012) [Daly, Theory of Deference]. 


\section{THE SCOPE OF THE POST-DUnSMUIR FRAMEWORK}

The framework first set out in Dunsmuir and elaborated in subsequent cases provides as follows. Correctness, which allows a reviewing court to substitute its judgement for that of the administrative decision-maker, ${ }^{9}$ applies to (1) constitutional issues, (2) questions of general law both of central importance to the legal system as a whole and outside the adjudicator's specialized area of expertise, (3) the drawing of jurisdictional lines between two or more competing specialized tribunals, (4) "true" questions of jurisdiction or vires, ${ }^{10}$ and (5) situations in which a court and an administrative decision-maker "may each have to consider the same legal question at first instance."11

Reasonableness is normally the governing standard where the question at issue (1) relates to the interpretation of the tribunal's home statute or statutes closely connected to its function, with which it will have particular familiarity, (2) raises issues of fact, discretion or policy, or (3) involves inextricably intertwined legal and factual issues. ${ }^{12}$ This has become known as the "categorical approach" to determine the intensity with which reviewing courts scrutinize administrative decisions. It largely replaces the previous "pragmatic and functional analysis," a much more contextual inquiry, ${ }^{13}$ to which reviewing courts are to resort only where the categorical approach is "unfruitful" 14 or "if the relevant precedents appear to be inconsistent with recent developments in the common law principles of judicial review."” 15

But there is a critical question which precedes the application of the categorical approach: to which class of decisions does it apply? On the one hand, the Court has stated that the common law of judicial review "must be sufficiently elastic to apply to the decisions of hundreds of different 'types' of administrators, from Cabinet members to entry-level fonctionnaires, who operate in different decision-making environments under different statutes with distinct grants of decision-making powers." ${ }^{16}$ This formulation suggests that the post-Dunsmuir framework applies to all decisions taken by administrative decision-makers that are reviewable by the federal courts or provincial superior courts.

"When undertaking a correctness review, the court may undertake its own reasoning process to arrive at the result it judges correct”: Law Society of New Brunswick v Ryan, 2003 SCC 20, [2003] 1 SCR 247 at para 50 .

Rogers Communications Inc v Society of Composers, Authors and Music Publishers of Canada, 2012 SCC 35, [2012] 2 SCR 283 at para 15 [Rogers]. But the scope of this category is limited: Re Sound v Fitness Industry Council of Canada, 2014 FCA 48, 455 NR 87 at para 49 [Re Sound]; Paul Daly, "Courts and Copyright: Some Thoughts on Standard of Review" in Michael Geist, ed, The Copyright Pentalogy: How the Supreme Court of Canada Shook the Foundations of Canadian Copyright Law (Ottawa: University of Ottawa Press, 2013) 47 [Daly, “Courts and Copyright”].

$12 \quad$ Alliance Pipeline, supra note 2 at para 26.

$13 \quad$ For discussion of the post-Dunsmuir framework, compare Paul Daly, "The Unfortunate Triumph of Form over Substance in Canadian Administrative Law” (2012) 50:2 Osgoode Hall LJ 317 (a critical take, in which the author maintains that the categorical approach does not remove the need for an appreciation of context) with Andrew Green, "Can There Be Too Much Context in Administrative Law? Setting the Standard of Review in Canadian Administrative Law” (2014) 47:2 UBC L Rev 443 (a generally positive take which emphasizes institutional considerations favouring a categorical approach). For an overview of the historical development of Canadian judicial review doctrine, see Paul Daly, "The Struggle for Deference in Canada” in Hanna Wilberg \& Mark Elliott, eds, The Scope and Intensity of Substantive Review: Traversing Taggart's Rainbow (Oxford: Hart, 2015). Dunsmuir, supra note 1 at para 62.

Agraira v Canada (Minister of Public Safety and Emergency Preparedness), 2013 SCC 36, [2013] 2 SCR 559 at para 48 [Agraira].

Khosa, supra note 6 at para 28. 
On the other hand, during the discussion of the general principles of judicial review in Dunsmuir, the Court — in both the French and English language versions — toggled between administrative "decision-makers" and administrative "tribunals." 17 There was thus a legitimate question whether Dunsmuir applied only to administrative tribunals and not to certain other classes of administrative decision-makers. ${ }^{18}$

It now seems that this question has been definitively resolved. The post-Dunsmuir framework is dominant, albeit that delegated legislation adopted in a legislative capacity is apparently an exception.

\title{
A. Substantive ReVIEW
}

In the wake of Dunsmuir, the Federal Court of Appeal generally refused to grant deference to ministerial interpretations of law. ${ }^{19}$ Justice Mainville, in the most extensive treatment of the question, cited concerns about the rule of law and separation of powers:

\begin{abstract}
What the Minister is basically arguing is that the interpretation ... favoured by his Department and by the government's central agencies, such as the Department of Justice, should prevail. The Minister thus seeks to establish a new constitutional paradigm under which the Executive's interpretation of Parliament's laws would prevail insofar as such interpretation is not unreasonable. This harks back to the time before the Bill of Rights of 1688 where the Crown reserved the right to interpret and apply Parliament's laws to suit its own policy objectives. It would take a very explicit grant of authority from Parliament in order for this Court to reach such a far-reaching conclusion. ${ }^{20}$
\end{abstract}

In light of these concerns, there could be no presumption that a ministerial interpretation of law was entitled to deference. Instead, a full standard of review analysis would have to be conducted.

Yet these concerns were brushed aside by the Court in Agraira, a case involving a discretionary decision by the Minister to refuse to admit A as a permanent resident of Canada. The first question for the Court was whether deference was owed to the Minister in the exercise of this discretionary power, especially in light of the interpretive element involved. Without a detailed explanation, the Court "confirmed" the "applicability" of the reasonableness standard on the basis that the decision was one of fact, discretion, or policy requiring the Minister to interpret his home statute. ${ }^{21}$

Compare e.g. Dunsmuir, supra note 1 at paras 35, 47 (“tribunals”), and at paras $48-49$ (“decision makers").

Toussaint v Canada (AG), 2011 FCA 213, [2013] 1 FCR 374 at para 19.

Though see Takeda Canada Inc v Canada (Minister of Health), 2013 FCA 13, [2014] 3 FCR 70 at para 33, Stratas JA.

See David Suzuki Foundation v Canada (Fisheries and Oceans), 2012 FCA 40, [2013] 4 FCR 155 at para 98.

Agraira, supra note 15 at para 50. In the author's view, this is the correct result. All of the substantive reasons that favour deference to administrative decision-makers' interpretations of law apply with equal if not greater force to ministerial departments: delegations of authority have been made, on the basis of the institutional competence of the departments in question. Concerns about the separation of powers are overblown. Legislative grants of authority in broad terms are a feature of the modern administrative state. Any problems they present are not unique to grants of authority to ministers and their departments. But it is entirely possible that in some cases deference would not be appropriate. Indeed, the Federal Court of Appeal has, post-Agraira, apparently remained hostile to the idea of deferring to ministerial interpretations of law. See e.g. Canada (Minister of Citizenship and Immigration) v Kandola, 2014 FCA 
Similarly, in McLean v. British Columbia (Securities Commission), ${ }^{22}$ the Court applied the post-Dunsmuir framework to an interpretation of law advanced by the Commission in litigation. It apparently took for granted that the post-Dunsmuir framework applied even though the matter came before the courts by way of a statutory appeal, rather than judicial review. ${ }^{23}$ In his majority reasons, Justice Moldaver neither mentioned nor addressed the implications of this procedural route.

Significantly, in Canadian National, ${ }^{24}$ a decision of the Governor-in-Council was subjected to the post-Dunsmuir framework. ${ }^{25}$ Justice Rothstein commented in general terms: "The precedents instruct that the Dunsmuir framework applies to administrative decision makers generally and not just to administrative tribunals."26

Yet in Katz Group Canada Inc. v. Ontario (Health and Long-Term Care), ${ }^{27}$ a case involving a set of regulations passed by a provincial cabinet, Dunsmuir was not as much as mentioned in passing. Combating high prices and the failure of various actors in the supply chain to pass savings on to consumers has proved to be a difficult battle for the province. The effort which gave rise to this litigation involved using a statutory power to impose "conditions" on participation in the generic drug market. ${ }^{28}$ These conditions had the effect of removing from the market a class of vertically integrated pharmaceutical companies. The Court held that this was permissible. If vertical integration were allowed, "strong incentives to keep these prices high" would remain. ${ }^{29}$ Because the impugned regulations were "part of the regulatory pursuit of lower prices for generic drugs and are, as a result, consistent with the statutory purpose," ${ }^{30}$ they were lawful.

In reaching this result the Court took a classical approach, treating delegated legislation as reviewable only for vires and not for substance. The applicants had argued amongst other things that the delegated legislation failed to achieve the purpose of reducing the cost of generic prescription drugs. The Court took a dim view of the propriety of embarking on such an inquiry:

It is not an inquiry into the underlying “political, economic, social or partisan considerations”.... Nor does the vires of regulations hinge on whether, in the court's view, they will actually succeed at achieving the statutory objectives... They must be "irrelevant”, "extraneous" or "completely unrelated” to the statutory

85, 372 DLR (4th) 342 at para 43 (citizenship of a child conceived by artificial means):

Specifically, there is no privative clause and the citizenship officer was saddled with a pure question of statutory construction embodying no discretionary element. The question which he was called upon to decide is challenging and the citizenship officer cannot claim to have any expertise over and above that of a Court of Appeal whose sole reason for being is resolving such questions. See also Justice Mainville's comment in dissent: "assuming without clear legislative authority that Parliament intends to defer to the executive for the interpretation of its laws is, in my view, a paradigm shift in the fabric of Canada's constitution” (ibid at para 86).

2013 SCC 67, [2013] 3 SCR 895 [McLean].

Securities Act, RSBC 1996, c 418, s 167(1).

Supra note 5.

A point that was not clear. See generally, Globalive Wireless Management Corp v Public Mobile Inc, 2011 FCA 119, [2011] FCJ No 483 (QL).

Canadian National, supra note 5 at para 54.

2013 SCC 64, [2013] 3 SCR 810 [Katz].

Drug Interchangeability and Dispensing Fee Act, RSO 1990, c P.23, s 14(1); Ontario Drug Benefit Act, RSO 1990, с O.10, s 18(1).

Katz, supra note 27 at para 34.

Ibid at para 38. 
purpose to be found to be ultra vires on the basis of inconsistency with statutory purpose.... In effect, although it is possible to strike down regulations as ultra vires on this basis..., "it would take an egregious case to warrant such action”. ${ }^{31}$

The effect is that the substance of regulations cannot be reviewed. Their rationality is irrelevant (save perhaps in an egregious case); only their legality matters, and the merits of anything intra vires is effectively unreviewable.

Compare the conclusion in Katz with the following statement in Catalyst Paper ${ }^{32}$ — a case involving judicial review of a municipal taxation bylaw — made by Chief Justice McLachlin for a unanimous Court:

\begin{abstract}
Unlike Parliament and provincial legislatures which possess inherent legislative power, regulatory bodies can exercise only those legislative powers that were delegated to them by the legislature. Their discretion is not unfettered. The rule of law insists on judicial review to ensure that delegated legislation complies with the rationale and purview of the statutory scheme under which it is adopted. The delegating legislator is presumed to intend that the authority be exercised in a reasonable manner. Numerous cases have accepted that courts can review the substance of bylaws to ensure the lawful exercise of the power conferred on municipal councils and other regulatory bodies. ${ }^{33}$
\end{abstract}

The assumption in Catalyst Paper was that the post-Dunsmuir framework applied. But in Katz, Dunsmuir is not mentioned, not even for the proposition that "true" questions of jurisdiction are reviewable on a correctness basis. There is a reference to United Taxi Drivers' Fellowship of Southern Alberta v. Calgary (City), ${ }^{34}$ a vires case, but for a proposition about statutory interpretation, not judicial review. ${ }^{35}$

Of course, Catalyst Paper dealt with municipal bylaws, not delegated legislation, and not with the originating authority under which the bylaws were passed. In Katz, Justice Abella relied on Thorne's Hardware Ltd. v. The Queen, ${ }^{36}$ a case in which the Court addressed the validity of an Order-in-Council. The federal Cabinet sought to extend the boundaries of a harbour so as to encompass property owned by an oil company. Amongst other things, the company claimed that the Order-in-Council had been adopted for the improper purpose of subjecting it to harbour dues. The Court refused to entertain this argument, as the federal Cabinet "quite obviously believed” that there were "reasonable grounds" to adopt the Orderin-Council and it was not for the reviewing court to "enquire into the validity of those beliefs.”37 Justice Dickson drew a distinction between unreviewable matters of policy and reviewable matters of law:

I have no doubt as to the right of the courts to act in the event that statutorily prescribed conditions have not been met and where there is therefore fatal jurisdictional defect. Law and jurisdiction are within the ambit of judicial control and the courts are entitled to see that statutory procedures have been properly

Ibid at para 28 [citations omitted].

Supra note 7.

Ibid at para 15 [emphasis added].

2004 SCC 19, [2004] 1 SCR 485.

Katz, supra note 27 at para 26.

[1983] 1 SCR 106 [Thorne's Hardware].

Ibid at 115. 
complied with. Decisions made by the Governor in Council in matters of public convenience and general policy are final and not reviewable in legal proceedings. Although, as I have indicated, the possibility of striking down an order in council on jurisdictional or other compelling grounds remains open, it would take an egregious case to warrant such action. ${ }^{38}$

Three decades on, however, this distinction between law and policy seems dubious. ${ }^{39}$ It is inconsistent with Catalyst Paper and with the decision of the United Kingdom Supreme Court in Bank Mellat v. Her Majesty's Treasury (No. 2). ${ }^{40}$ This case involved a statutory instrument rather than a regulation, but one which was "a measure targeted against identifiable individuals" 41 just as the Ontario regulation was targeted at identifiable pharmaceutical companies. Consider the following passage from the speech of Lord Sumption:

\begin{abstract}
If a statutory power to make delegated legislation is subject to limitations, the question whether those limitations have been observed goes to the lawfulness of the exercise of the power. It is therefore reviewable by the courts. In principle, this applies as much to an implied limitation as to an express one, and as much to a limitation on the manner in which the power may be exercised as it does to a limitation on the matters which are within the scope of the power. ${ }^{42}$
\end{abstract}

This does not mean that review of regulations would be particularly intrusive. In Catalyst Paper, the Court imposed a very deferential standard: was the bylaw one that no reasonable municipality could have adopted? A similar standard applied here would presumably have led to the same result. ${ }^{43}$

It is certainly appropriate to draw distinctions between regulations passed under statutory authority and various other types of decision-making processes. The question is whether they all inhabit the galaxy of the post-Dunsmuir framework, ${ }^{44}$ adapted slightly for different contexts, or whether a fragmented approach should be adopted.

There are good arguments against a fragmented approach. For one thing, the result for the individual on the receiving end is usually the same regardless of the form the decision takes. For another thing, administrative decision-makers are given incentives to use particular forms of decision for reasons unrelated to whether the use of a particular form would serve the purpose of good administration. If Ontario had attempted to achieve its goals by way of an

\footnotetext{
Ibid at 111 [citations omitted]. See Part IV.A below.

[2013] UKSC 39, [2014] 1 AC 700.

Ibid at para 46 [emphasis added].

Ibid at para 43.

See e.g. $R v$ Secretary of State for the Environment, ex parte Hammersmith and Fulham London Borough Council, [1991] 1 AC 521 (HL); Nottinghamshire County Council v Secretary of State for the Environment, [1986] AC 240 (HL). There is no doubt that there is strong authority for the Court's approach, though most of it is decades old. Nonetheless, it is problematic, as is any decision that shields areas of government action from review for substance. Why should the government not have to justify the adoption of regulations if an applicant has demonstrated that the regulations have perverse effects (such as the exclusion of some forms of corporate structure from a market but not others)? After all, the government has to justify individual decisions that have perverse effects. Less should be required in respect of delegated legislation if there has been legislative scrutiny. But something should still be required.

$44 \quad$ Khosa, supra note 6 at para 28. Khosa concerned the application of the post-Dunsmuir framework to federal decision-makers, so one would expect that the same would be true in the provinces. Yet while "Cabinet members" come under the post-Dunsmuir framework, apparently Cabinet itself does not!
} 
administrative decision rather than by way of a regulation, its action would have been subjected to a greater degree of scrutiny. Substantive review of all types of administrative action under the same framework simplifies matters greatly for all those concerned. Finally, review of delegated legislation often involves an analysis of whether discriminatory treatment, or an outright prohibition on activity, was authorized by statute. ${ }^{45}$ This is precisely the sort of substantive matter that in other contexts is examined for reasonableness. The failure to bring regulations under Dunsmuir is very disappointing. At the very least, some explanation of why regulations are to be treated differently would have been helpful.

In Canadian National, Justice Rothstein distinguished Katz on the basis that a challenge had been made to the vires of regulations adopted in a "legislative capacity." 46 There is a revealing contrast with Martin v. Alberta (Workers' Compensation Board), ${ }^{47}$ where the postDunsmuir framework was applied to a set of administrative policies that a provincial board had issued to determine eligibility for federal workers' compensation benefits. ${ }^{48}$ There was no obvious difficulty posed by reviewing the policies for reasonableness. Delegated legislation adopted by a politically accountable body acting in a "legislative capacity" seems then to be the sole type of delegated decision-making that does not fall under the postDunsmuir framework.

It is curious that the post-Dunsmuir framework was breezily presumed to apply in Agraira, McLean, and Martin, but did not feature at all in Katz. Had the Court seriously considered the appropriate scope of the post-Dunsmuir framework in any of these cases, it might not have fallen into the trap in Katz of failing to consider whether substantive review of regulations should be available, and would not have, in Canadian National, introduced a "legislative capacity" test that will have to be further defined. ${ }^{49}$

\section{B. Procedural RevieW}

Historically, judges have developed and enforced the rules of procedural fairness. Little or no deference is owed to procedural choices made by administrative decision-makers: "procedural issues ... are to be determined by a court on the basis of a correctness standard of review." 50 Yet this orthodoxy has recently been strongly challenged.

In $R e$ Sound, ${ }^{51}$ Justice Evans wrote of the importance of giving weight to procedural choices made by administrative decision-makers:

In short, whether an agency's procedural arrangements, general or specific, comply with the duty of fairness is for a reviewing court to decide on the correctness standard, but in making that determination it must be respectful of the agency's choices. It is thus appropriate for a reviewing court to give weight to the manner in which an agency has sought to balance maximum participation on the one hand, and efficient and effective

Montréal v Arcade Amusements Inc, [1985] 1 SCR 368.

Canadian National, supra note 5 at para 51.

2014 SCC 25, [2014] 1 SCR 546 [Martin].

See similarly, Campbell v Workers' Compensation Board (Sask), 2012 SKCA 56, 393 Sask R 246.

An analogy might be made to the Statutory Instruments Act, RSC 1985, c S-22, s 2(1)(a), which defines as a "regulation" a statutory instrument that, inter alia, is "made in the exercise of a legislative power conferred by or under an Act of Parliament” [emphasis added].

Khosa, supra note 6 at para 43.

Supra note 11. 
decision-making on the other. In recognition of the agency's expertise, a degree of deference to an administrator's procedural choice may be particularly important when the procedural model of the agency under review differs significantly from the judicial model with which courts are most familiar. ${ }^{52}$

Two other appellate judges have used the post-Dunsmuir framework as the launch pad for a frontal attack on the orthodox approach. In Syndicat des travailleuses et travailleurs de ADF - CSN c. Syndicat des employés de Au Dragon Forgé inc. ${ }^{53}$ Justice Bich deferred to the Quebec Labour Relations Board's denial of a union party's request for access to the identity of a group of employees. It was argued that this was a matter of procedural fairness because it went to the union's ability to give a full answer and defence in the proceedings before the Board and thus reviewable on a standard of correctness. However, in determining this question the Board had to interpret and apply its home statute. Applying the post-Dunsmuir framework, Justice Bich held that the Board was subject to review on a deferential standard. ${ }^{54}$ Justice Bich concluded that the Board had, on the facts, struck the necessary reasonable balance $^{55}$ between the principle of audi alteram partem and the statutory objectives of protecting the identity of employees involved in labour disputes. ${ }^{56}$

In Maritime Broadcasting System Ltd. v. Canadian Media Guild, ${ }^{57}$ a series of procedural fairness arguments was made subsequent to the certification of a bargaining unit by the Canadian Industrial Relations Board. After reconsideration of procedural issues relating to the application of the Board's own policies, additional submissions made by one party, and the denial of an oral hearing, the Board maintained its original position.

Writing only for himself, Justice Stratas recast the Canadian law on procedural fairness. First, he emphasized the importance of context in resolving questions of procedural fairness, noting that Canadian courts have long appreciated that administrative decision-makers, not reviewing courts, are best placed to appreciate the relevant context. ${ }^{58}$ Second, he underlined that, in the post-Dunsmuir framework, reasonableness is the presumptive standard of review where an expert decision-maker is acting within its domain of specialization. ${ }^{59}$ Third, cases decided before Dunsmuir and never overruled either accorded deference or referred to the possibility of deference on procedural matters. ${ }^{60}$

Ibid at para 42 .

2013 QCCA 793, [2013] RJQ 831 (QL) [Au Dragon Forgé].

Moreover, Justice Bich noted, deference on this sort of question was consistent with the approach of the Supreme Court of Canada in Doré v Barreau du Québec, 2012 SCC 12, [2012] 1 SCR 395, where a deferential standard was applied to a disciplinary tribunal's interpretation of the Charter right to freedom of expression: ibid at paras 44-45.

Ibid at para 49.

Ibid at para 61.

2014 FCA 59, 373 DLR (4th) 167 [Maritime Broadcasting].

Ibid at para 50 .

Ibid at paras 51-53.

Ibid at para 54 . 
In the instant case, Justice Stratas held that deference ought to be accorded:

In my view, the case at bar is one where the Board should be given some leeway under reasonableness review. The Board understood the requirements of procedural fairness, citing two of its own decisions that were based on relevant jurisprudence from the Supreme Court of Canada. The Board's task in this case was to apply those standards in a discretionary way to the factually complex matrix before it, a task informed by its appreciation of the dynamics of the case before it and its knowledge of how its procedures should and must work, all in discharge of its responsibility to administer labour relations matters fairly, justly and in an orderly and timely way. It did so under the umbrella of legislation empowering the Board to consider its own procedures based on its appreciation of the particular circumstances of cases and to vary or depart from those procedures when it considers it appropriate....

Maritime Broadcasting does not point to any particular misunderstanding of the Board as to the relevant legal concepts. Rather, it invites us to stand in the shoes of the Board and apply the principles in this case. As I have said, this is inapt. ${ }^{61}$

Undoubtedly, the company had particular procedural rights, in particular to notice and to an opportunity to make submissions. But the Board's determination of the content of these rights was entitled to deference.

Significantly, there are now three categories of case in which Canadian courts have deferred to administrative determinations of procedural fairness questions. On the scope of procedural fairness, there is the (relatively) old, unrepudiated authority of Bibeault $v$. McCaffrey ${ }^{62}$ On whether a particular right exists, there is Justice Bich's decision in $A u$ Dragon Forgé. And now, on the content of procedural fairness, there is Maritime Broadcasting (as well as the remarks of Justice Evans in Re Sound) which, moreover, involves a set of discretionary decisions by the Board rather than the interpretation of a statutory provision (as was the case in Bibeault and Au Dragon Forge).

The case for deference on questions of procedural fairness is thus being made ever more loudly. Yet the outcome is not a foregone conclusion; the UK Supreme Court recently rejected deference, ${ }^{63}$ and the deferential turn in the Canadian cases is by no means uniform. ${ }^{64}$ However, the Court's recent insistence on orthodoxy rings somewhat hollow. ${ }^{65}$ Even if it

Ibid at paras 63-64 [citation omitted]. Moreover, he criticized Justice Evans' approach in Re Sound, supra note 11, an approach which would accord "weight" to administrative decision-makers' choice of procedural arrangements. Justice Stratas wrote that describing the giving by courts of weight to administrative decision-makers' procedural determinations is a "non-sequitur," "like describing a car as stationary but moving” (at para 60). This recalls an American quarrel. So-called Skidmore deference also involves the giving of "weight" to determinations of administrative decision-makers: Skidmore $v$ Swift \& Co, 323 US 134 (1944) [Skidmore]. In a memorable dissent in United States v Mead Corp, 533 US 218 (2000), Justice Scalia described Skidmore deference as "an empty truism and a trifling statement of the obvious: A judge should take into account the well-considered views of expert observers" (at 250). Skidmore nonetheless remains an important part of American administrative law. See e.g. Peter L Strauss, “'Deference' is Too Confusing - Let's Call Them 'Chevron Space' and 'Skidmore Weight”" (2012) 112:5 Colum L Rev 1143. I suggest that the desire to recognize "weight" as something distinct from correctness and reasonableness is evidence of the need for three standards of review in Canadian law. See Parts V.D and V.E, below.

$62 \quad$ [1984] 1 SCR 176.

63 Osborn v The Parole Board (2013), [2013] UKSC 61, [2014] AC 1115.

64 See e.g. Rezmuves v Canada (Minister of Citizenship and Immigration), 2013 FC 973, [2015] 1 FCR 366.

$65 \quad$ Mission Institution v Khela, 2014 SCC 24, [2014] 1 SCR 502 at para 79. 
could be said that the jurisprudence has "satisfactorily" established correctness as the standard of review of procedural fairness claims, "the relevant precedents appear to be inconsistent with recent developments in the common law principles of judicial review,"66 as the appellate jurisprudence has pointed out.

Whether procedural questions fall under the post-Dunsmuir framework at all and, if so, what categories they fall into is therefore a live question. And it must be said that the logic underpinning the post-Dunsmuir framework strongly suggests that procedural questions too should often be subject to review on a deferential standard. ${ }^{67}$

\section{THE SCOPE OF THE CORRECTNESS CATEgorieS}

Six years on from Dunsmuir, the Court took the opportunity presented by Canadian National to define two of the correctness categories: "true" questions of jurisdiction or vires; and questions of general law of central importance to the legal system falling outside the expertise of a particular specialized decision-maker. The significance of this development is best understood after a consideration of McLean. ${ }^{68}$ This too is a significant case about the scope of the correctness categories, as much for what it does not say as for what it actually says.

$M$ had misconducted herself in the Ontario securities market in the early 2000s. She and the Ontario Securities Commission eventually arrived at a settlement in 2008. M was barred from activities in Ontario. Subsequently, the British Columbia Securities Commission ("the Commission”) took action against $\mathrm{M}$ under a statutory provision that allows it to impose sanctions on a person who "has agreed with a securities regulatory authority, a self regulatory body or an exchange, in Canada or elsewhere, to be subject to sanctions, conditions, restrictions or requirements.”69

The difficulty raised by $\mathrm{M}$ was that the Commission cannot commence proceedings "more than 6 years after the date of the events that give rise to the proceedings."70 The key question was the meaning of the term "events"; if the term referred to the underlying misconduct, the limitation period had expired before the Commission imposed the sanctions on $\mathrm{M}$, but if the term included the conclusion of the settlement agreement, then the Commission's action was not time-barred. The parties more or less lined up behind these alternative interpretations.

In its analysis, the majority of the Court reaffirmed the "categorical" approach set out in Dunsmuir. ${ }^{71}$ Here, $\mathrm{M}$ argued cogently that the question of the proper interpretation of the limitation period provision was one of general law of central importance to the legal system.

Agraira, supra note 15 at para 48.

See generally, Paul Daly, “Canada’s Bi-Polar Administrative Law: Time for Fusion” (2014) 40:1 Queen's LJ 214.

Supra note 22.

Securities Act, supra note 23, s 161(6)(d).

Ibid, s 159.

As has been observed elsewhere, however, the appeal of these categories is superficial; as in previous decisions, the Court had to do quite a bit of work to find the appropriate category: Paul Daly, "Dunsmuir's Flaws Exposed: Recent Decisions on Standard of Review” (2012) 58:2 McGill LJ 483 [Daly, “Dunsmuir's Flaws Exposed”]. 
Such provisions appear in securities statutes across the country. And the underlying principles of limitation of actions are common to public and private law regimes.

Yet the Court — as it has almost always done since Dunsmuir ${ }^{72}$ — applied a standard of reasonableness. Justice Moldaver gave three reasons. First, while limitation periods "are generally of central importance to the fair administration of justice, it does not follow that the Commission's interpretation of this limitation period must be reviewed for its correctness." ${ }^{73}$ Second, the possibility of divergent outcomes across the country did not provide "a basis for correctness review" but was rather an inevitable "function of our Constitution's federalist structure."74 Third, the decision-maker did have expertise with regard to the interpretation of limitation periods, contrary to the applicant's suggestion that the issue fell outside the specialized knowledge of a securities regulator:

While such a view may have carried some weight in the past, that is no longer the case. The modern approach to judicial review recognizes that courts "may not be as well qualified as a given agency to provide interpretations of that agency's constitutive statute that make sense given the broad policy context within which that agency must work."75

Despite the vaunted simplicity of the categorical approach, ${ }^{76}$ the Court had to do a great deal of explaining to justify the choice of reasonableness as the standard of review. So much for simplicity. ${ }^{77}$ Nonetheless, the Court chastised counsel who make "fashionable" claims for correctness review. ${ }^{78}$ Yet given the uncertain scope of the correctness categories - and the advantage of having a second kick at the can if the correctness standard applies counsel would be doing a disservice to their clients if they were not to make such claims. Notably, McLean itself contained no guidance on the scope of the correctness categories: the standard of review was resolved only by reference to external factors and not by means of definition of the categorical approach.

This was of a piece with the treatment of true questions of jurisdiction or vires in Alberta Teachers'. There, Justice Rothstein pronounced himself “unable to provide a definition” of such a question, ${ }^{79}$ but twice emphasized that true jurisdictional questions are "exceptional" and concluded without further explanation that this was not such an exceptional case. In

Nolan v Kerry (Canada) Inc, 2009 SCC 39, [2009] 2 SCR 678 (claim of jurisdictional error); Nor-Man Regional Health Authority Inc v Manitoba Association of Health Care Professionals, 2011 SCC 59, [2011] 3 SCR 616 [Nor-Man Regional Health Authority] (question of general law); Alberta Teachers', supra note 2 (jurisdictional error); Communications, Energy and Paperworkers Union of Canada, Local 30 v Irving Pulp \& Paper Ltd, 2013 SCC 34, [2013] 2 SCR 458 [Irving Paper SCC]. A correctness standard was applied to a jurisdictional issue in Northrop Grumman Overseas Services Corp v Canada (AG), 2009 SCC 50, [2009] 3 SCR 309, but only because previous case law had satisfactorily identified the appropriate standard (at para 10).

McLean, supra note 22 at para 28 [emphasis in original].

Ibid at para 29.

Ibid at para 31 [citations omitted].

For a subtle defence, see Green, supra note 13.

One is tempted to ask: why not just double down on Dunsmuir and apply a standard of reasonableness all the time? Maybe it is time to do away with these categories altogether and impose reasonableness review across the board. As David Mullan notes, however, this might require the Court to revisit the constitutional basis of judicial review, see supra note 3. Given the Court's reluctance to engage in grand theorizing, the probability of this happening is low.

McLean, supra note 22 at para 25.

Alberta Teachers', supra note 2 at para 42.

Ibid at paras 34, 39. 
McLean, ${ }^{81}$ the Court tantalizingly cited with approval an American case in which deference was accorded to a decision-maker's interpretation of its jurisdiction, ${ }^{82}$ but the Court did not abolish the category of jurisdictional questions.

Other occasions on which the Court could have usefully elaborated on the scope of the correctness categories were also passed up. In Irving Paper SCC, ${ }^{83}$ the employer had unilaterally imposed mandatory random alcohol testing for employees holding safety sensitive positions. Labour law principles are clear here: a test of reasonableness applies to any such unilateral imposition. ${ }^{84}$ In the present case, a majority of the arbitration board concluded that the invasion of employee privacy rights was not justified by the evidence presented to it.

\title{
Interestingly, the Court of Appeal made a clever plea for correctness review:
}

\begin{abstract}
In my view, the answer to the question is subject to the review standard of correctness for two reasons. First, the question posed raises a pure question of law, one that seeks to strike a reasonable balance between an employer's legitimate interest and obligation to provide a safe workplace and the privacy and dignity interests of employees or, in some instances, their freedom from discrimination. As such, the case raises a question of general importance in the law over which the arbitration board cannot assert a greater relative expertise than the courts. Indeed, some might argue that at its core this appeal is of importance to the public at large having regard to the location of the kraft mill. Second, the arbitral jurisprudence is not always reconcilable or easily so. Often, the same case is cited for opposing propositions. Moreover, the distinction which the arbitration board makes between dangerous and ultra dangerous workplaces is simply not part of the arbitral framework surrounding the validity of alcohol and drug testing policies. The same holds true in regard to the requirement that the employer adduce evidence of a significant alcohol or drug problem in the workplace. Hence, it falls on this Court to provide certainty so far as the law of New Brunswick is concerned. $^{85}$
\end{abstract}

The cleverness here lies in the suggestion of criteria which would determine whether a question is one of general law of central importance to the legal system. The Court ignored the suggestion, simply stating that it "cannot be seriously challenged" that the standard of review of arbitral decisions is reasonableness. ${ }^{86}$

There was further silence on the scope of the correctness categories in Bernard v. Canada $(A G),{ }^{87}$ another case in which the problem was presented. $\mathrm{B}$, an employee of the Canada Revenue Agency, was a member of a bargaining unit, though she refused to join the union. The case came before the Public Service Relations Board as an unfair practices matter. ${ }^{88}$ The employer had refused to release home contact details, to the chagrin of the union. The Board concluded that the refusal interfered with the union's task of representing the bargaining unit and ordered that home contact details be released.

Supra note 22 at para 25, n 3.

Arlington (City of), Texas v Federal Communications Commission, 133 S Ct 1863 (2013) [Arlington]. Supra note 72.

Re Lumber \& Sawmill Workers’ Union, Local 2537 and KVP Co (1965), 16 LAC 73 (Robinson). Communications, Energy and Paperworkers Union of Canada, Local 30 v Irving Pulp \& Paper Ltd, 2011 NBCA 58, 375 NBR (2d) 92 at para 5 [emphasis in original] [Irving Paper CA]. Irving Paper SCC, supra note 72 at para 7. 2014 SCC 13, [2014] 1 SCR 227 [Bernard SCC].

Under the Public Service Labour Relations Act, SC 2003, c 22, s 2. 
At this point, B got wind of the case and commenced judicial review proceedings. She was successful. The Federal Court of Appeal ${ }^{89}$ remitted the matter to the Board to address whether the order was compatible with the Privacy Act. ${ }^{90}$ When the matter was remitted to it, the Board had to address whether the order that an employer had to disclose home contact information of non-union employees was compatible with privacy legislation. In particular, it had to ask whether disclosure to the union would be consistent with "the purpose for which the information was obtained" as per section 8(2)(a) of the Privacy Act. But the Privacy Act is not something that the Board encounters on a regular basis. Was its interpretation nonetheless entitled to deference?

At the Federal Court of Appeal, Justice Evans justified a deferential approach by noting that the issue was not one of "general application" of the Privacy Act but turned on findings of fact made in the labour relations context in which the Board is undoubtedly expert and entitled to deference. ${ }^{91}$ There was no "readily extricable question of more general application that would elevate it to one of statutory interpretation” because the Board was applying the Privacy Act "to a labour relations context, its undisputed area of expertise."92

But even though the issue was teed up perfectly for it, the Supreme Court skipped over it almost entirely, saying only:

In our view, the Board made a reasonable determination in identifying the union's proposed use as being consistent with the purpose of contacting employees about terms and conditions of employment and in concluding that the union needed this home contact information to carry out its representational obligations "quickly and effectively". 93

No principled basis was advanced for deferring to the Board's decision, even though it involved interpreting the Privacy Act. ${ }^{94}$ In the absence of a statement of principle it is difficult to know if anything of general application can be taken from the Court's decision in Bernard. It fits a general pattern in which the Court has almost without fail eschewed the interventionist correctness standard, though often without offering much by way of explanation.

It is now necessary to consider Canadian National, a rate regulation case involving an agreement between Peace River Coal and CN. The parties had a contract into which was incorporated a fuel surcharge provision. After the contract was concluded, $\mathrm{CN}$ issued a new fuel surcharge provision. This provision had a higher ceiling that would have benefited Peace River, so it asked CN to implement it. CN refused. Arguing that the old provision was now unreasonable, Peace River sought the intervention of the Canadian Transportation Agency. It refused, on the basis that the contract between the parties was confidential and thus outside the Agency's authority. Rather than seek judicial review of the Agency, Peace River convinced its trade association to petition the federal Cabinet to rescind the Agency's

Bernard v Canada (AG), 2010 FCA 40, 398 NR 325.

RSC 1985, c P-21.

Bernard v Canada (AG), 2012 FCA 92, [2012] 4 FCR 370 at para 36.

Ibid at para 37.

Bernard SCC, supra note 87 at para 33 [citation omitted].

See similarly Canadian Artists' Representation v National Gallery of Canada, 2014 SCC 42, [2014] 2 SCR 197 at para 13. 
decision. Cabinet did so. CN sought judicial review, contending that Cabinet has no authority to rescind Agency decisions on questions of law.

Justice Rothstein applied a standard of reasonableness, on the basis that the matter fell within the expertise of Cabinet, a conclusion supported by Cabinet's historical role in regulatory matters. ${ }^{95}$ It was not a question of general law of central importance to the legal system. It was "particular to this specific regulatory regime as it involves confidential contracts... and the availability of a complaint-based mechanism that is limited to shippers that meet the statutory conditions," a question which did not "have precedential value outside of issues arising under this statutory scheme." 96 Nor was it jurisdictional:

To the extent that questions of true jurisdiction or vires have any currency, the Governor in Council's determination of whether a party to a confidential contract can bring a complaint under s. 120.1 does not fall within that category. This is not an issue in which the Governor in Council was required to explicitly determine whether its own statutory grant of power gave it the authority to decide the matter (see Dunsmuir, at para. 59). Rather, it is simply a question of statutory interpretation involving the issue of whether the s. 120.1 complaint mechanism is available to certain parties. This could not be a true question of jurisdiction or vires of the Governor in Council — the decision maker under review in this case. ${ }^{97}$

This is the first clear sight since Dunsmuir of criteria for these correctness categories. This is welcome. Although "fashionable" claims for correctness review were derided by Justice Moldaver in McLean, the references to (i) "precedential value” in the context of a "specific regulatory regime” and (ii) explicit determinations whether a decision-maker’s "statutory grant of power gave it the authority" to decide a question provide a set of criteria to determine whether questions fall within the "general question of law" and "true jurisdiction" categories. ${ }^{98}$ (The latter, of course, mirrors the definition given in Dunsmuir, but given the doubts over the continued existence of the category, one might have thought that the Court would take the opportunity to reduce its scope.)

An inevitable side effect is that the very existence of clear criteria will increase the number and volume of "fashionable" correctness claims. Indeed, the categories are now more broadly drawn than they might have been. It is often the case - or at least, often said to be the case - that decision-makers have to determine explicitly the scope of their statutory authority. ${ }^{99}$ Short of the abolition of the category, a narrower definition would be "interpretation of a provision that the decision-maker does not administer or with which it is not familiar." ${ }^{100}$ And, in defining questions of general law of central importance to the legal system, the Court did not include as a criterion the importance of uniformity. Both the Quebec and Alberta Courts of Appeal have recently suggested in the context of professional

Canadian National, supra note 5 at paras 57-58.

Ibid at para 60 .

Ibid at para 61 [emphasis added].

McLean, supra note 22.

For some surprisingly broad appellate examples, see e.g. Lysohirka v British Columbia (Workers' Compensation Board), 2012 BCCA 457, 39 BCLR (5th) 15, (power to reconsider a decision considered jurisdictional); Newfoundland and Labrador Hydro $v$ Newfoundland and Labrador (Board of Commissioners of Public Utilities), 2012 NLCA 38, 323 Nfld \& PEIR 127 (refusal to exercise authority to disperse to energy consumers funds collected from industrial customers considered jurisdictional). This definition is consistent with Bernard SCC, supra note 87, which concerned an application of a general provision in a particular context rather than an abstract interpretation, and the endorsement in McLean of Arlington, supra note 82. 
privilege that the need for uniform application of a legal principle is what sets this category apart. ${ }^{101}$ Again, short of abolition, this seems like a sensible limitation. Further refinement of the categories may therefore be expected.

\section{REASONS AND REASONABLENESS REVIEW}

Paragraph 47 of Dunsmuir is well-known for its elaboration of a unified standard of reasonableness, with two prongs. Administrative decision-makers must make decisions that bear the hallmarks of "justification, transparency and intelligibility" and that fall "within a range of possible, acceptable outcomes.”102

Less well-known, at least until recently, was the rhetorical flourish in the following paragraph. Citing Professor Dyzenhaus, Justices Bastarache and LeBel noted that courts should pay "respectful attention to the reasons offered or which could be offered in support of a decision.” 103 Dyzenhaus' concern was that reviewing courts should not intervene in situations where a decision-maker had not necessarily joined all the dots in her reasoning in a way satisfactory to a judicial mind. And the Court signaled its understanding of this concern in Newfoundland and Labrador Nurses' Union v. Newfoundland and Labrador (Treasury Board). ${ }^{104}$ Justice Abella noted that “decision-makers routinely render decisions in their respective spheres of expertise, using concepts and language often unique to their areas and rendering decisions that are often counter-intuitive to a generalist." ${ }^{105}$ Her appreciation of context led her to a sensible doctrinal prescription: "Reasons may not include all the arguments, statutory provisions, jurisprudence or other details the reviewing judge would have preferred, but that does not impugn the validity of either the reasons or the result under a reasonableness analysis.”106

This passage is unobjectionable. It comports with the spirit of Professor Dyzenhaus' essay on deference. “Justification, transparency and intelligibility,” described in Dunsmuir as the hallmarks of reasonableness, have now become a test of whether the reviewing court can "clearly understand" the reasoning behind the decision. ${ }^{107}$ This does not invite judicial abdication. As was explained in Komolafe v. Canada (Minister of Citizenship and Immigration):

Newfoundland Nurses is not an open invitation to the Court to provide reasons that were not given, nor is it licence to guess what findings might have been made or to speculate as to what the tribunal might have been thinking. This is particularly so where the reasons are silent on a critical issue. It is ironic that

See e.g. Association des pompiers professionnels de Québec inc c Québec (Ville de), 2013 QCCA 2084, [2013] JQ No 17122 (QL); Imperial Oil Ltd v Alberta (Information and Privacy Commissioner), 2014 ABCA 231, 580 AR 125 [Imperial Oil]. See also Fédération autonome de l'enseignement c Commission scolaire de Laval, 2014 QCCA 591, [2014] JQ No 2352 (QL) (claim of deliberative secrecy by school board raising question of general law of central importance to the legal system). Dunsmuir, supra note 1 at para 47.

103 David Dyzenhaus, "The Politics of Deference: Judicial Review and Democracy” in Michael Taggart, ed, The Province of Administrative Law (Oxford, UK: Hart, 1997) 279 at 286. 2011 SCC 62, [2011] 3 SCR 708 [Newfoundland Nurses].

Ibid at para 13 .

Ibid at para 16. See also Canada Post Corp v Public Service Alliance of Canada, 2010 FCA 56, [2011] 2 FCR 221 at para 163 [Public Service Alliance], Evans JA, dissenting ("perfection is not the standard"), rev'd 2011 SCC 57, [2011] 3 SCR 572; Irving Paper SCC, supra note 72 at para 54 (“The board's decision should be approached as an organic whole, without a line-by-line treasure hunt for error"). Agraira, supra note 15 at para 90. 
Newfoundland Nurses, a case which at its core is about deference and standard of review, is urged as authority for the supervisory court to do the task that the decision maker did not do, to supply the reasons that might have been given and make findings of fact that were not made. This is to turn the jurisprudence on its head. Newfoundland Nurses allows reviewing courts to connect the dots on the page where the lines, and the direction they are headed, may be readily drawn. Here, there were no dots on the page. ${ }^{108}$

Regrettably, the Court has recently departed radically from the spirit of "deference as respect," which treats reasoned decision-making as the sine qua non of deference. ${ }^{109}$

\section{A. DECISION-MAKERS SUPPLEMENTING THE RECORD}

In Alberta Teachers', the Court was presented with an interesting problem. The Commissioner commenced an investigation into complaints that data had been unlawfully disclosed, an investigation that was to be completed within 90 days. ${ }^{110}$ Between the commencement of the investigation and the completion of the inquiry, the Commissioner employed its power to extend the 90-day timeline. But this was done only some 22 months after the initial complaint had been received.

The problem was the Commissioner had not formally given a decision on the timeline issue, though as Justice Rothstein concluded, a finding that the failure to invoke the power was not fatal to jurisdiction was necessarily implicit in the Commissioner's decision. ${ }^{111}$ The key factor here was the existence of a plausible basis for the Commissioner's implicit decision. In related decisions of the Commissioner in respect of legislation within its purview, a consistent approach had been taken to the timelines issue. In the circumstances, the absence of a set of formal reasons did not inhibit the Court from subjecting the Commissioner's approach to reasonableness review. ${ }^{112}$

This is relatively unobjectionable. One would rarely expect an administrative decisionmaker to give reasons for a decision not to use a power. Moreover, its position had been laid out in other decisions, and the individuals concerned could doubtless have complained (thereby seeking and receiving a reasoned decision) had they wanted to.

But in McLean, paragraph 48 of Dunsmuir was stretched to its breaking point. In its very brief order ${ }^{113}$ — so brief that the British Columbia Court of Appeal considered appellate review "impossible" and remanded the matter for further reasons ${ }^{114}$ — the Commission did not explain its interpretation of the limitation period provision. It simply made an order barring $\mathrm{M}$ from activities in British Columbia for the same periods that she was barred from activities in Ontario.

2013 FC 431, 16 Imm LR (4th) 267 at para 11. See e.g. Leahy v Canada (Minister of Citizenship and Immigration), 2012 FCA 227, [2014] 1 FCR 766; Wall v Independent Police Review Director, 2013 ONSC 3312, 362 DLR (4th) 687, aff'd 2014 ONCA 884, 123 OR (3d) 574. See e.g. David Dyzenhaus, "Constituting the Rule of Law: Fundamental Values in Administrative Law" (2002) 27:2 Queen’s LJ 445. Personal Information Protection Act, SA 2003, c P-6.5, s 50(5), as amended by Personal Information Protection Amendment Act, SA 2009, c 50.

Alberta Teachers', supra note 2 at para 29.

Ibid at paras 53-55.

Re McLean, 2010 BCSECCOM 262, 2010 LNBCSC 222 (QL).

2011 BCCA 455, 343 DLR (4th) 432 at para 30. 
The fact that the Commission did not explain its interpretation of the term "events" did not particularly worry the Supreme Court of Canada:

\begin{abstract}
Unlike Alberta Teachers, in the case at bar, we do not have the benefit of the Commission's reasoning from its decisions in other cases involving the same issue.... However, a basis for the Commission's interpretation is apparent from the arguments advanced by the respondent, who is also empowered to make orders under (and thus to interpret) s. 161(1) and (6). These arguments follow from established principles of statutory interpretation. Accordingly, though reasons would have been preferable, there is nothing to be gained here from requiring the Commission to explain on remand what is readily apparent now. ${ }^{115}$
\end{abstract}

This is important but troubling. Canadian courts have been taking a somewhat laissez-faire attitude towards after-the-fact rationalizations of administrative decisions. In Saskatchewan (Energy and Resources) v. Areva Resources Canada Inc., ${ }^{116}$ the Ministry did not offer any interpretation of the provision at issue at the time it made its decision on the amount of royalties due on uranium sales. After a judicial review application had been commenced, the Ministry duly filed a supporting affidavit explaining its position. Even though this was "an after-the-fact explanation" and "largely argumentative," Justice Cameron felt that these features "need not detain” the Court, because of Dunsmuir's reference to reasons that could be offered in support of a decision. ${ }^{117}$

One could imagine the applicant thinking it rather unfair that the Ministry won the case based on an argument elaborated on only after the dispute between the parties had arisen. A particularly angst-ridden applicant would doubtless think that maybe, just maybe, it could have mounted a better argument in its discussions with the Ministry had it only had the full details of the Ministry's position.

The United States provides an instructive contrast. Chevron deference ${ }^{118}$ is generally not paid to administrative decision-makers' interpretations of law advanced for the first time in litigation: "Deference to what appears to be nothing more than an agency's convenient litigating position would be entirely inappropriate." 119 And in determining whether agency decisions are arbitrary or capricious, ${ }^{120}$ litigation affidavits are said to be "post hoc rationalizations ... which have traditionally been found to be an inadequate basis for review."121

Far too much leeway is given in McLean to judges and administrative decision-makers by the admonition in Dunsmuir to pay attention to reasons that could have been offered for a decision. The individual subject to the authority of the administrative decision-maker should

$115 \quad$ McLean, supra note 22 at para 72.

1162013 SKCA 79, 365 DLR (4th) 99, leave to appeal to SCC refused, 35554 (13 February 2014).

117 Ibid at para 36. See also para 110 (reasons of Ottenbreit JA).

118 Chevron USA Inc v Natural Resources Defense Council Inc, 467 US 837 (1984) [Chevron].

119 Bowen (Secretary of Health and Human Services) v Georgetown University Hospital, 488 US 204 (1988) at 213. I use the word "generally" advisedly. Perhaps the consistency here between the Commission's order and the argument advanced before the courts persuaded the Court that remanding the matter would be futile and a waste of resources (though, as noted above, the British Columbia Court of Appeal had no such qualms about remanding). Nonetheless, the Court ought to have demonstrated some awareness of the principle it was laying down, one which is capable of being broadly construed. See generally, 5 USC § 706(2) (1966).

121 Citizens to Preserve Overton Park v Volpe (Secretary of Transportation), 401 US 402 (1971) at 419 [citation omitted]. 
have the opportunity to argue his or her case on the record in full knowledge of the decisionmaker's position on the relevant interpretive questions. ${ }^{122}$ Allowing a decision-maker to put a thumb on the scales after the event is unfair and prevents a full airing of all relevant issues. To ask courts to adopt a permissive approach on judicial review of a fully reasoned decision reached after an adjudicative process is one thing. To allow after-the-fact rationalizations for decisions which might have been reached on entirely different grounds is quite another.

\section{B. JUdiCIAL SUPPLEMENTATION OF AdMinisTRATIVE DECISIONS}

Allowing after-the-fact rationalizations has the potential to cause other difficulties. Where the decision-maker has said nothing at all, judicial-review judges are left to guess at its thinking and even ask counter-factuals about whether the decision would have been the same had the decision-maker put its mind to a particular point. Indeed, in Alberta Teachers', Justice Rothstein warned that respectful attention to reasons that could have been offered should not be treated as a "carte blanche to reformulate a tribunal's decision in a way that casts aside an unreasonable chain of analysis in favour of the court's own rationale for the result." 123

Consider, however, the facts of Agraira. The applicant was a Libyan national. Claiming that he had been a member of the Libyan National Salvation Front, he sought refugee status but was refused for want of sufficient involvement. This caused problems for him down the line. When he applied to become a permanent resident of Canada, he was deemed inadmissible because of his involvement in a terrorist organization. In short, he was not involved enough to be a refugee, but too involved to be admissible, something which undermined his credibility.

At that point, he requested ministerial relief on the basis of his unusual circumstances. Section 34(2) of the Immigration and Refugee Protection Act (which has now been repealed) provided that, although otherwise inadmissible, “a permanent resident or a foreign national who satisfies the Minister that their presence in Canada would not be detrimental to the national interest” will be treated as admissible. ${ }^{124}$

An immigration officer prepared a report in his favour. A briefing note from the Canada Border Services Agency also argued that the Minister should exercise his discretion in favour of the applicant. Yet the Minister did not follow this advice, concluding instead: "It is not in the national interest to admit individuals who have had sustained contact with known terrorist

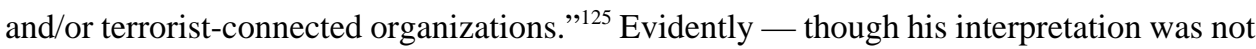

See e.g. Re Downing and Graydon (1978), 21 OR (2d) 292 at 314-15 (CA), Wilson JA (as she then was) ("it is not the factual basis alone that the appellant was entitled to respond to but also the legal basis of the employment standards officers' decision”), cited in Syndicat des employés de production du Québec et de l'Acadie v Canada (Human Rights Commission), [1989] 2 SCR 879 at 903. Alberta Teachers', supra note 2 at para 54, citing Petro-Canada v British Columbia (Workers' Compensation Board), 2009 BCCA 396, 98 BCLR (4th) 1 at para 56.

124 SC 2001, c 27, as repealed by Faster Removal of Foreign Criminals Act, SC 2013, c 16, s 13(3).

125 Agraira, supra note 15 at para 13. The Minister's supporting reasons were as follows:

After having reviewed and considered the material and evidence submitted in its entirety as well as specifically considering these issues:

- The applicant offered contradictory and inconsistent accounts of his involvement with the Libyan National Salvation Front (LNSF).

- There is clear evidence that the LNSF is a group that has engaged in terrorism and has used 
spelled out - the Minister considered involvement with terrorist organizations to be detrimental to Canada's "national interest." Judging by the decision, the Minister put determinative weight on terrorist involvement in determining whether it would be in the "national interest” to admit the applicant. ${ }^{126}$

Worse still, the Court imputed to the Minister an implied interpretation that he plainly did not hold. It was evident from the Minister's decision that almost exclusive emphasis was placed on the applicant's alleged terrorist connections. The Court's interpretation was much more subtle. Although it was not problematic that the Minister's interpretation "related predominately to national security and public safety," ${ }^{127}$ it also had to include considerations set out in soft law guidelines, considerations including such matters as the individual's activities in Canada and family situation. ${ }^{128}$ Had the more subtle interpretation that the Court considered reasonable been adopted by the Minister the outcome of the case could well have been very different. Yet Mr. Agraira lost the case, because the Court concluded that the Minister's decision (based on the implied interpretation that the Court arrived at after the fact) was reasonable. ${ }^{129}$

How can a reviewing court see into the mind of an administrative decision-maker and answer counter-factuals about what the decision-maker would have done had different arguments been made? The answer is that it cannot, and should be much more forthcoming in the use of its power to remand decisions for clarification. Fairness to the individuals subject to the authority of administrative decision-makers requires no less. It is time for the Court to narrowly cabin paragraph 48 of Dunsmuir and confine Newfoundland Nurses to its particular context, situations where reviewing courts must “analyze sparse reasons given by an administrative tribunal." 130

terrorist violence in attempts to overthrow a government.

- There is evidence that LNSF has been aligned at various times with Libyan Islamic opposition groups that have links to Al-Qaeda.

- It is difficult to believe that the applicant, who in interviews with officials indicated at one point that he belonged to a "cell" of the LNSF which operated to recruit and raise funds for LNSF, was unaware of the LNSF's previous activity.

There was also an issue as to the applicant's credibility, but this went only to the extent of his involvement with the terrorist organization. It could not have been an independent ground for refusing the application on the basis of "national interest." Agraira, supra note 15 at para 62.

Ibid at Appendix 1. Section 9.2 of the Guidelines (reproduced in Appendix 1) included the following:

- the details of the application and any personal or exceptional circumstances to be taken into consideration; this would include:

- $\quad$ details of immigration application;

- $\quad$ basis for refugee protection, if applicable;

- $\quad$ other grounds of inadmissibility, if applicable;

- $\quad$ activities while in Canada;

- details of family in Canada or abroad;

- $\quad$ any Canadian interest.

Ibid at paras 89-90.

Lemus v Canada (Minister of Citizenship and Immigration), 2014 FCA 114, 372 DLR (4th) 567 at para 35, Stratas JA. Justice Stratas, at para 33, posed but did not answer a series of pertinent questions:

One might well query the idea that reviewing courts are to presume the correctness of administrators' decisions, even in the face of a defect. One might also query whether, in trying to sustain an outcome reached by flawed reasoning, the reviewing court might be coopering up an outcome that the administrator, knowing of its error, might not have itself reached. Finally, whether an outcome should be left in place because of the strength of the record or other considerations has traditionally been something for the remedial stage of the analysis, not an earlier stage.

See also the choice of remedy, at paras 38-39. 


\section{THE Rise of Difficult Distinctions}

Dunsmuir's project was to simplify the law. Unfortunately, in its treatment of the reasonableness standard, the Court has developed or revived a clutter of difficult distinctions that make life more difficult for lawyers, litigants, and reviewing courts. Distinctions between law and policy, implied and express interpretations, clear and unclear statutory provisions, and interpretation and application are emerging to undermine the apparent simplicity of the post-Dunsmuir framework.

\section{A. LAW AND Policy}

A very troublesome distinction is found in Katz, which revives the distinction between "legality" and "policy" in judicial review of regulations adopted by a cabinet. It had seemed that Catalyst Paper had put a stake through the heart of Thorne's Hardware, ${ }^{131}$ a case involving review of Governor-in-Council decisions. Here is what Chief Justice McLachlin said in Catalyst Paper:

Against this general background, I come to the issue before us - the substantive judicial review of municipal taxation bylaws. In [Thorne's Hardware], the Court, referring to delegated legislation, drew a distinction between policy and legality, with the former being unreviewable by the courts:

The Governor in Council quite obviously believed that he had reasonable grounds for passing Order in Council P.C. 1977-2115 extending the boundaries of Saint John Harbour and we cannot enquire into the validity of those beliefs in order to determine the validity of the Order in Council.

... However, this attempt to maintain a clear distinction between policy and legality has not prevailed. In passing delegated legislation, a municipality must make policy choices that fall reasonably within the scope of the authority the legislature has granted it. Indeed, the parties now agree that the tax bylaw at issue is not exempt from substantive review in this sense. ${ }^{132}$

But as far as delegated legislation goes, the distinction between policy and legality is back. Courts are not to assess "the policy merits of ... regulations." ${ }^{\text {133 }}$ Challenges to vires only are permissible and, even then, courts should intervene only in egregious cases. ${ }^{134}$ Thorne's Hardware has risen from the dead. ${ }^{135}$ 


\section{B. IMPLIED AND EXPRESS COMPONENTS OF DECISIONS}

Another difficult distinction emerged in Agraira. Having reviewed the Minister's laconic set of reasons, Justice LeBel took the view that an interpretation of law was "necessarily implied within his ultimate decision on ministerial relief." 136 This is a slightly different situation from the Alberta Teachers' case, ${ }^{137}$ where deference was accorded to the decisionmaker even though it had not set out its interpretive position in the proceedings. There, however, the decision-maker had interpreted the statutory term at issue in similar factual settings and was (in the Court's view) following a settled understanding in the instant case. The same cannot be said of the Minister here. Rather, in exercising his discretion, the Minister necessarily had to interpret section 34(2) and, in particular, the meaning of the term "national interest."

Analytically, this is surely correct. Often, interpretations of law are left unspoken, lurking just beneath the surface of a decision. However, the concept of the "implied interpretation of law" may offer an invitation to reviewing courts to segment a decision into "implied" and “express” components, which is doubly problematic.

To begin with, it adds a layer of complexity to the law. And if the "implied" components are said to be "legal," or "jurisdictional," more searching judicial review could easily be justified. Segmenting administrative decisions in this way has the potential to reduce the degree of deference accorded to decision-makers. Indeed, just such an outcome occurred in the present case. Justice LeBel held that the Minister's implied interpretation was "consistent with Driedger's modern approach to statutory interpretation.” ${ }^{139}$ Here, the Minister's decision was reasonable only because it accorded with the result reached on the application of judicial principles of statutory interpretation. Put another way, the Minister was reasonable because he was right. ${ }^{140}$ But this surely cannot be the test for the reasonableness (as opposed to the wrongness) of an interpretation of law, implied or otherwise.

The Court would have been better not to have mentioned the concept of "implied" interpretations at all. The question should have been whether the Minister's decision was reasonable in terms of the facts and relevant legal provisions. Assessing reasonableness in this manner would not have given rise to additional complexity. A better approach was laid out by Justice Stratas in Canada (Minister of Transport, Infrastructure and Communities) $v$ Farwaha ${ }^{141}$ a case involving the revocation of an individual's security clearance. To the applicant's contention that the decision should be segmented, Justice Stratas responded in forthright terms:

Overall, the Minister was to decide whether Mr. Farwaha's security clearance should be cancelled. That is how the Minister approached his decision. The standards applied by the Minister to the matter before him

$136 \quad$ Agraira, supra note 15 at para 58.

$137 \quad$ Supra note 2.

138 Now, presumably, deference could be afforded to an interpretation advanced by the minister in litigation. See above, text to nn 8-10.

139 Agraira, supra note 15 at para 64.

140 See similarly Dionne v Commission scolaire des Patriotes, 2014 SCC 33, [2014] 1 SCR 765; Martin, supra note 47; Ontario (Community Safety and Correctional Services) v Ontario (Information and Privacy Commissioner), 2014 SCC 31, [2014] 1 SCR 674. 
— including the Minister's assessments of the quality and weight to be given to the evidence — are part and parcel of the overall decision he made. For the purposes of assessing the standard of review, the Minister's decision should be assessed in its totality. ${ }^{142}$

Hopefully, the distinction between "implied" and "express" components of decisions will not exert significant influence in future cases.

\section{Clear and UnClear Statutory Provisions}

The Federal Court of Appeal, ${ }^{143}$ New Brunswick Court of Appeal, ${ }^{144}$ and Ontario Court of Appeal ${ }^{145}$ each has independently suggested that where the application of the traditional tools of statutory construction gives a "clear" answer to a question of statutory interpretation, courts are duty bound to insist upon it. Deference will only be given if the term in question is ambiguous. In the absence of ambiguity, the "range" is limited to one reasonable outcome:

[I]f a reviewing court concludes that one interpretation is “right”, after conducting a textual, contextual, and purposive interpretative analysis of the legislation, and giving careful and respectful consideration to the tribunal's reasons, correctness is the standard of review. In these circumstances, if a tribunal has interpreted the statute in some other way, the court may intervene to ensure administrative compliance with the legislature's clearly expressed intention. The rule of law requires nothing less. ${ }^{146}$

In McLean, Justice Moldaver took a similar approach, though without referring to the appellate jurisprudence. He explained that where use of "the ordinary tools of statutory interpretation" would identify "a single reasonable interpretation," any other interpretation "will necessarily be unreasonable": "In those cases, the 'range of reasonable outcomes' ... will necessarily be limited to a single reasonable interpretation — and the administrative decision maker must adopt it." ${ }^{147}$

This distinction between clear and unclear statutory provisions is problematic. ${ }^{148}$ For one thing, it causes a contradiction within the post-Dunsmuir approach. It is said on the one hand that administrative decision-makers are to benefit from a presumption of reasonableness when interpreting their home statutes. ${ }^{149}$ But on the other hand it is said that the courts by applying the general principles of statutory interpretation will define the "range" of reasonableness. Yet determining the "range" of reasonable interpretations necessarily involves an interpretation of the decision-maker's home statute. To apply the principles of statutory interpretation to this end is to defeat the presumption of deference.

$142 \quad$ Ibid at para 81

143 Canada (AG) v Canada (Canadian Human Rights Commission), 2013 FCA 75, 444 NR 120 [Canadian Human Rights Commission 2013]; Qin v Canada (Minister of Citizenship and Immigration), 2013 FCA 263, [2015] 1 FCR 313 [Qin].

$144 \quad$ Small v New Brunswick Liquor Corp, 2012 NBCA 53, 390 NBR (2d) 203.

145 Ontario (Alcohol and Gaming Commission) v 751809 Ontario Inc, 2013 ONCA 157, 115 OR (3d) 24.

$146 \quad$ Qin, supra note 143 at para 33.

147 McLean, supra note 22 at para 38 [citation omitted].

For a full-fledged assault on this approach, see Paul Daly, “Unreasonable Interpretations of Law” (2014) 66 SCLR (2d) 233. 
There is a further contradiction in treating deferentially administrative decision-makers' application of (and deviation from ${ }^{150}$ ) general common law concepts ${ }^{151}$ but insisting on a legalistic application of principles such as the presumption against tautology. ${ }^{152}$ It is unrealistic to expect non-lawyers to think like lawyers and it is inappropriate to require them to do so when legislatures have chosen them rather than judges to answer crucial regulatory questions. ${ }^{153}$

Finally, the idea that administrative decision-makers operate within an interpretive "range" should send a chill down the spine of anyone familiar with the history of administrative law. A test that requires courts to enforce "clear" legislative provisions is jurisdictional error on steroids. Just as a test of jurisdictional error proved malleable and liable to lead to contradictory results, so too will the McLean approach.

\section{APPLICATION AND INTERPRETATION}

Another problem lurks in McLean. Having commented in general terms about the "range" of reasonable outcomes, Justice Moldaver then went on to assess the reasonableness of the Commission's interpretation. Having regard to the ordinary meaning, legislative history, and context of the limitation period provision, he took the view that both M's preferred interpretation and the Commission's interpretation were reasonable. With the Commission's thumb on the scales because of the deference afforded to its after-the-fact explanation of its position, the Court had no choice but to uphold the Commission's interpretation. ${ }^{154}$

Justice Moldaver then acknowledged that the Commission's interpretation could lead to harsh results in individual cases. Regulatory stacking could occur, whereby successive penalties could be imposed by different provinces based not on the initial misconduct but on subsequent enforcement proceedings: ${ }^{155}$ "Common sense suggests that the authorities will always want more time to go after law-breakers, but fairness demands their chase eventually come to an end." 156

In such cases, Justice Moldaver suggested, the Commission's decisions could well be unreasonable. ${ }^{157}$ But there is an analytical problem with this argument. If the Commission's interpretation (that "events" included the settlement agreement) was within the "range" of reasonable interpretations of the statute, how could a harsh application of that interpretation be unreasonable? Justice Moldaver suggests that as far as questions of law go, all that matters is that the interpretation falls within a particular "range." But if that is so, even a harsh application must be upheld. ${ }^{158}$

Marine Services International Ltd v Ryan Estate, 2013 SCC 44, [2013] 3 SCR 53 at para 82.

Nor-Man Regional Health Authority, supra note 72.

Canada (Canadian Human Rights Commission) v Canada (AG), 2011 SCC 53, [2011] 3 SCR 471

[Canadian Human Rights Commission 2011].

Daly, “Dunsmuir's Flaws Exposed,” supra note 71.

McLean, supra note 22 at paras 40-41, 59.

Ibid at para 61.

Ibid at para 64.

Ibid at paras 65-66.

The Commission had advanced a subtle position to address the "stacking" issue. Justice Moldaver recognized the "eminent good sense" of the "concessions" but did nonetheless not endorse them (ibid at para 67). It is unfortunate that these issues were not worked out in argument and on the record before the Commission. Had the issues been allowed to percolate in various enforcement proceedings and on 
The analytical problem is that two distinct questions have been conflated. The "range" of the decision-making authority granted to the Commission is an important consideration. ${ }^{159}$ But when the reasonableness of a decision is called into question, a court must ask itself a distinct question: "Was the decision unreasonable?" The answer to this question does not necessarily turn on the interpretation of the statute, for there may be other considerations at issue such as the rationality or harshness of the resulting decision, or its compatibility with fundamental values of the legal system. ${ }^{160}$ Treating "range” as the be-all and end-all of judicial review of interpretations of law is a mistake.

The only way to avoid the analytical problem is to make a distinction between an interpretation and the application of the interpretation to a particular set of facts. ${ }^{161}$ Justice Moldaver could say that both the interpretation and application were reasonable in the present case but that in a future case although the interpretation would remain reasonable it could be applied unreasonably. Yet the distinction between questions of law and questions of fact "is not purely objective, but must take account of factors of 'expediency' or 'policy." "162 To admit the distinction between interpretation and application is to re-admit the law/fact distinction as a key factor both in determining the "range" of unreasonableness and also in segmenting decisions into "legal" and "factual" elements. For all its failings, the pragmatic and functional analysis at least avoided this analytical problem, because it kept the factors which determined the intensity of review distinct from the task of review itself.

An elaboration of the concept of the "range" was attempted by Justice Stratas in Farwaha. ${ }^{163}$ The issue here was the revocation of the security clearance of an individual who worked in a port. He was suspected of involvement with the Hells Angels, which led the Minister to believe "there [was] a risk that [he would] be suborned to commit an act or to assist or abet any person to commit an act that might constitute a risk to marine transportation security."164 Justice Stratas concluded that the "range” of reasonable outcomes was quite broad in this case:

In some cases, Parliament has given a decision-maker a broad discretion or a policy mandate — all things being equal, this broadens the range of options the decision-maker legitimately has. In other cases, Parliament may have constrained the decision-maker's discretion by specifying a recipe of factors to be considered - all things being equal, this narrows the range of options the decision-maker legitimately has.

appeal to the British Columbia Court of Appeal, the Court might have avoided the analytical problem identified in the text.

See also Catalyst Paper, supra note 7 at para 18: "The fundamental question is the scope of decisionmaking power conferred on the decision-maker by the governing legislation. The scope of a body's decision-making power is determined by the type of case at hand.”

What was described in Canadian Human Rights Commission 2011, supra note 152 at para 22 as "basic consistency in the fundamental legal order."

161 McLean, supra note 22 at para 66. Justice Karakatsanis wrote a concurring set of reasons, in which she disagreed slightly with Justice Moldaver. However, although she essentially rejected the proposition that harsh outcomes could be unreasonable in particular cases, she did not identify the analytical problem. She preferred to rest her conclusion on "the legislative objectives of consistency and cooperation that underlie the secondary proceedings regime”, which would be thwarted by accepting the interpretation offered by the applicant (ibid at para 80). This approach has the merit of not running into analytical difficulty, though that would doubtless come as cold comfort to any individual against whom regulatory proceedings were 'stacked.' Ibid at para 66. v First Tier Tribunal (Social Entitlement Chamber), [2013] UKSC 19, [2013] 2 AC 48. 
In still other cases, the nature of the matter and the importance of the matter for affected individuals may more centrally implicate the courts' duty to vindicate the rule of law, narrowing the range of options available to the decision-maker.

In considering the breadth of the range of reasonableness available to the Minister in this case, I have considered the following:

- The Minister's decision is a matter of great importance to Mr. Farwaha, affecting the nature of his work, his finances, and his prospects for advancement.

- The decision concerns security matters. Wrong decisions can lead to grave consequences.

- $\quad$ Security assessments involve some policy appreciation and sensitive weighings of facts.

- The Minister's decision in this case requires assessments of risk based on whether reasonable grounds for suspicion exist. ${ }^{165}$

There is some attraction to this formulation, which is a sophisticated elaboration of the one set out by Justice Moldaver in McLean. ${ }^{166}$ On the surface, it would simplify administrative law greatly if the standard was reasonableness most or all of the time, subject only to the "range" expanding and narrowing depending on "all relevant factors."

However, it is not beyond criticism. Here is a (Canadian) spectrum of intensity of review:

$$
\begin{aligned}
\text { Correctness }-> & \text { Weight }->\text { Proportionality }->\text { Reasonableness }->\text { Patent } \\
& \text { Unreasonableness }->\text { Non-justiciability }
\end{aligned}
$$

Two things invariably matter: (1) how to decide where on the spectrum a decision lies and (2) how to define the various fixed points on the spectrum. In principle, there could be infinite points on the spectrum, between correctness and non-justiciability, but our creativity, time, and patience are limited.

The trend in Canada, of which Farwaha is the most recent evidence, is to develop an overarching "range" of "reasonableness." Yet despite its apparent simplicity, the "range" solution does not do away with the need to respond to (1) and (2). It fudges (1) by referring to "all relevant factors" and ignores (2) altogether, even though it is clear that the "range" narrows and expands depending on "all [the] relevant factors." For example, where the "range" allows only one "clear" answer, we are arguably in the correctness part of the spectrum above, and where the "range" is especially broad, we are arguably in the patent unreasonableness area, where a decision will be upheld if any relevant material can be

165 Farwaha, supra note 141 at paras 91-92.

166 Supra note 22. See also Justice Stratas’ formulation in Canadian Human Rights Commission 2013, supra note 143 at para 14 :

In this case, the range [of acceptable and defensible outcomes] is relatively narrow. The Tribunal's decision primarily involves statutory interpretation - a matter constrained by the text, context and purpose of the statute. It also involves equality law - a matter constrained by judicial pronouncements. In this case, the Tribunal had less room to manoeuvre than in a case turning upon one or more of factual appreciation, fact-based discretions, administrative policies, or specialized experience and expertise not shared by the reviewing court on the particular point in issue. 
provided in support of the decision. Justice Binnie's prophecy in his set of concurring reasons in Dunsmuir seems eerily accurate:

\begin{abstract}
"Contextualizing" a single standard of review will shift the debate (slightly) from choosing between two standards of reasonableness that each represent a different level of deference to a debate within a single standard of reasonableness to determine the appropriate level of deference. In practice, the result of today's decision may be like the bold innovations of a traffic engineer that in the end do no more than shift rush hour congestion from one road intersection to another without any overall saving to motorists in time or expense. $^{167}$
\end{abstract}

The problem is that while (1) and (2) can be hidden, they cannot be eliminated. If we hide them, the law in practice becomes confused and confusing because nobody knows what factors are admissible or what weight they are given. And (1) and (2) are conflated, recreating the problem that Justice Moldaver ran into in McLean. It is doubtful that this ultimately represents an improvement on the old pragmatic and functional analysis, in which both (1) and (2) were distinct. While (2) was poorly defined, this is even more true of the new "range" approach. And (1) was defined as a fixed group of four considerations in the pragmatic and functional analysis, whereas it is now an amorphous and unpredictable set of factors.

\title{
E. Reasoning Process and Substantive Outcomes
}

The difficulties the Court has inadvertently created in its elaboration of the reasonableness standard are perhaps a product of a failure to think in broad terms about the meaning of reasonableness. Instead of a sustained attempt to articulate the reason and structure of review for reasonableness, the Court has instead offered bromides about reasonableness taking colour from its “context," a context created by “all relevant factors." 168 These mask important differences in the way judges approach judicial review cases.

Consider Irving Paper, which raises in stark form the difficulty of distinguishing clearly between a decision-maker's reasoning process and the substantive outcomes arrived at. Both the first-instance court ${ }^{169}$ and the New Brunswick Court of Appeal ${ }^{170}$ quashed the decision. A particular bone of contention was a distinction made by the board between "ultradangerous” and merely “dangerous” workplaces. ${ }^{171}$ Surely, Justice Robertson held, once it is accepted that catastrophic harm can result from a breakdown at a particular facility, any such distinction is flawed. ${ }^{172}$

By way of a majority decision by Justice Abella, the Court restored the board's decision, though taking care not to endorse the distinction between the dangerous and the ultradangerous. As she explained, relying on the arbitral jurisprudence, a balancing exercise is necessary. Employees' privacy rights, on one side, versus risks to safety, on the other. ${ }^{173}$ On 
the facts, there were eight incidents over a 15-year period. Justice Abella concluded that the arbitrator was entitled reasonably to come to the conclusion that this evidence did not outweigh the invasion of the employees’ privacy interests.

Justices Rothstein and Moldaver filed a lengthy set of dissenting reasons, which was joined by Chief Justice McLachlin. Their quibble was that the board had imposed an unduly onerous evidentiary standard, one that did not reflect "the arbitral consensus" 174 because it instead required a “'significant' or 'serious' problem” with alcohol use and a causal connection between such use "and a workplace incident."

One reading of recent Canadian cases on the application of the reasonableness standard is that two distinct approaches are emergent: the restorative (in which reviewing courts strive to present a decision in the best possible light, so as to uphold it) and the restrictive (in which reviewing courts approach decisions with scepticism and look closely for error). ${ }^{176}$ Here, it is as if the majority and dissenting judges read two entirely different arbitral decisions.

Indeed, the particular issue in Irving Paper gives reason to suspect that a single reasonableness standard which is concerned with both the reasoning process and the substantive outcome of that process might be inherently unstable. Both the majority and dissenting justices were happy to allow the arbitral jurisprudence to set the parameters of the board's decision. ${ }^{177}$ There was no question of the Court revising or doing away with important parts of a body of labour law that has been long in the making by expert decisionmakers. A difficulty with this approach is that although there may be serious flaws in a decision-maker's reasoning, its reasoning will nonetheless set the framework for future decision-makers. Courts cannot intervene because administrative decision-makers are not held to a standard of perfection. ${ }^{178}$ Yet without intervention (judicial or otherwise), decisions could become progressively less and less reasonable. In this case, the troublesome ultradangerous/dangerous distinction would have been at large in the arbitral jurisprudence. One can understand (without necessarily agreeing) why Justices Moldaver and Rothstein — or any other judges — might have been concerned about this prospect.

However, that concern is difficult to express in terms of the single reasonableness standard. It would be more satisfactory (1) for courts to focus "on the outcome reached by the administrative decision-maker with due regard to any significant problems in its reasoning" "179 and (2) to recognize two distinct standards of reasonableness, one which is satisfied by any relevant material but one which requires cogent and convincing reasoning from the decision-maker. ${ }^{180}$ If two deferential standards were recognized — an intermediate

\footnotetext{
$174 \quad$ Ibid at para 104.

$175 \quad$ Ibid at para 105.

176 Matthew Lewans, “Deference and Reasonableness Since Dunsmuir” (2012) 38:1 Queen’s LJ 59. Irving Paper SCC, supra note 72 at paras 6, 16, 42, 64, 75.

Public Service Alliance of Canada v Canada Post Corp, 2011 SCC 57, [2011] 3 SCR 572.

Forest Ethics Advocacy Association v Canada (National Energy Board), 2014 FCA 245, [2014] FCJ No 1089 (QL) at para 62.

180 Paul Daly, A Theory of Deference in Administrative Law: Basis, Application and Scope (Cambridge: Cambridge University Press, 2012) ch 4 [Daly, Theory of Deference], where I attempt to elaborate welldefined standards of deferential review. Another possibility would be to use the factors discussed in Farwaha (Part V.B, above) as a means of setting the range of reasonable outcomes. In Irving Paper SCC, supra note 72 the dissenting judges evidently believed the range was restricted because legalistic tests played an important role in the board's decision. By contrast, the majority judges plainly took the
} 
one which relied on cogency and a deferential one which relied on relevancy ${ }^{181}$ - the disagreement in this case would have been much more transparent. ${ }^{182}$ The majority judges would have upheld the decision because it was based on relevant material; the minority would have dissented on the basis that the board's reasoning lacked cogency. Both majority and minority would have had to justify openly their choice of standard and explain their underlying concerns (though the minority would have had a hard time justifying interventionist review of a manifestly expert adjudicative tribunal). ${ }^{183}$ Readers would more clearly understand what is at stake in the choice of standard of review and what factors might be appropriate in making it. Enveloping these important issues into a one-size-fits-all reasonableness standard which bifurcates process and outcomes is unhelpful. ${ }^{184}$

\section{CONCLUSION}

Some of the problems identified in this essay could be solved in a relatively straightforward manner. The post-Dunsmuir framework could easily be applied broadly. Laxity in the search for reasons that "could be offered" in support of a decision could be resolved by remitting matters for further reasons. Instability in the operation of the reasonableness standard could be countered by recognition of a more deferential standard of review. And the attempt to oversimplify judicial review by introducing a set of troublesome distinctions is simply unnecessary.

The broader problem, however, is that the Court is not at present given to broad theorizing about the general principles of judicial review. This may represent the calm before the storm. Since the landmark Canadian Union of Public Employees, Local 963 v. New Brunswick Liquor Corporation decision of $1979,{ }^{185}$ major recalibrations of Canadian administrative law doctrine have taken place at roughly 10-year intervals: U.E.S., Local 298 v. Bibeault; ${ }^{186}$ Canada (Director of Investigation and Research) v. Southam Inc.; ${ }^{187}$ and Dunsmuir. ${ }^{188}$ But where incremental change and improvement is possible, action should be taken. Another major upheaval could be averted by the adoption by the Court of a measured approach involving careful engagement with the thoughtful efforts of appellate judges across the country to better explain and develop the common law of judicial review.

view that the board's decision turned on an appreciation of factual issues, on which the range of reasonable outcomes would presumably be more extensive. Of course, this approach does not respond to the troublesome distinction between process and outcome.

Or perhaps one based on "weight" as Justice Evans suggested in Re Sound, supra note 11. See discussion in notes 52 and 61, above. See also the reference by the Alberta Court of Appeal to the concept of "limited deference" in Imperial Oil, supra note 101 at para 43.

This is the position the author defends in Daly, Theory of Deference, supra note 179.

See Irving Paper SCC, supra note 72 at para 75 for a game attempt.

Also at issue here may have been the "characterization" problem. One has to decide what a decision says before determining whether it is reasonable: see Daly, "Courts and Copyright," supra note 11. Here, the majority treated the decision as a balancing exercise; it seemed as if the evidence simply did not satisfy the board that the interference with privacy rights was justified. But the dissenting judges, accused by Justice Abella of going on a "line-by-line treasure hunt for error" (Irving Paper SCC, ibid at para 54) saw an impermissibly elevated evidentiary standard. Even if one accepts that both of these readings of the board's decision were reasonably open to the reviewing court, a properly deferential court should adopt the reasonable reading over the unreasonable one. Trading rhetorical barbs about the intrusiveness of review strikes me as less helpful than a frank recognition that, in reading administrative decisions, two possibilities are often present and in choosing between them a court can be more or less deferential. [1979] 2 SCR 227.

[1988] 2 SCR 1048.

[1997] 1 SCR 748.

Supra note 1. 